\title{
RLUIPA's Equal-Terms Provision's Troubling Definition of Equal: Why the Equal-Terms Provision Must Be Interpreted Narrowly
}

\section{INTRODUCTION}

Protestors gathered outside a meeting of the Manhattan Community Board 1 in mid-August 2010. ${ }^{1}$ The board was holding a public-comment period followed by a vote on the contentious Ground Zero mosque, otherwise known as Park51. The proposed development included a thirteen-story Muslim cultural center housing, among other uses, a mosque and an auditorium. ${ }^{2}$ Burlington Coat Factory abandoned the building shortly after September 11, 2001 when the landing gear from a plane that struck a World Trade Center tower crashed through its roof. ${ }^{3}$ "You're building over a Christian cemetery!" one sign read. ${ }^{4}$ A supporter of the Muslim center countered, "I say bring it on. What a wonderful opportunity to teach tolerance." "In the end, the board had no choice but to approve the proposal. ${ }^{6}$

A few weeks earlier, with the Statue of Liberty serving as his backdrop, New York City Mayor Michael Bloomberg praised another local body, the Landmarks Preservation Commission, for allowing the project to advance saying that "we would betray our values if we were to treat Muslims differently than anyone else." Among signs that read

\footnotetext{
* Sean Foley. J.D. candidate 2012, University of Kansas School of Law; B.A. 2006, Truman State University. I would like to thank Professor Stephen R. McAllister for his generous advice and invaluable feedback throughout this process. Also, thanks to the Kansas Law Review board and staff-especially Brian Duerksen and Colin Baumchen - for their hard work and dedication. Lastly, I would like to thank my friends and family, especially Tom, Sheila, and Patrick Foley for their encouragement and Erin for her patience and support.

1. Megan K. Scott, et al., After Fiery Debate, Vote Approves Mosque Plans, NBC N.Y. (Aug 17, 2010, 4:03 PM), http://www.nbcnewyork.com/news/local/After-Firey-Debate-CommunityApproves-Mosque-Near-Ground-Zero-94909169.html.

2. Emily Geminder, 45 Park Place's Place, N.Y. OBSERVER, July 20, 2010, 9:25 PM, http://www.observer.com/2010/real-estate/45-park-places-place.

3. Id.

4. Scott et al., supra note 1 .

5. Id.

6. Id.

7. Michael Barbaro \& Javier C. Hernandez, Mosque Plan Clears Hurdle in New York, N.Y.
} 
"This mosque celebrates our murders"8 and "Don’t glorify murders of $3,000, " 9$ a firefighter injured on September 11 vowed to challenge the decision in court. $^{10}$ Several prominent politicians, including Newt Gingrich and Sarah Palin, called the decision offensive. ${ }^{11}$

Mayor Bloomberg was likely reflecting his opinion that Muslims should be treated the same as members of other faiths, but he may well have been expressing relief. Had either local body rejected Park51, the city would have violated the equal-terms provision of the Religious Land Use and Institutionalized Persons Act (RLUIPA). The equal-terms provision provides, "No government shall impose or implement a land use regulation in a manner that treats a religious assembly or institution on less than equal terms with a nonreligious assembly or institution."12 In short, the provision attempts to force municipalities to treat religious assemblies equally as compared to other assemblies in land-use decisions. ${ }^{13}$

Three United States Courts of Appeals have produced separate tests. ${ }^{14}$ This Comment will discuss the history of the Free Exercise Clause that led to RLUIPA, outline the statute's structure and function,

Times, Aug. 4, 2010, at A1.

8. Karina Ioffee, NY Mosque Near September 11 Site Wins Approval, REUTERS, Aug. 3, 2010, 3:05 PM, http://www.reuters.com/article/idUSTRE67234X20100803?pageNumber=1.

9. Id.

10. Barbaro \& Hernandez, supra note 7, at A1.

11. Id.

12. 42 U.S.C. § 2000cc(b)(1) (2006).

13. See River of Life Kingdom Ministries v. Vill. of Hazel Crest, 611 F.3d 367, 371 (7th Cir. 2010) (en banc) (stating that a church and a community center must be treated equally when they do not differ regarding accepted zoning criteria).

14. See infra Part III. The Second and Tenth Circuits have also heard challenges under the equal-terms provision, but each resolved the issue without explicitly endorsing a test. See Third Church of Christ, Scientist, of N.Y.C. v. City of New York, 626 F.3d 667 (2d Cir. 2010); Rocky Mountain Christian Church v. Bd. of Cnty. Comm'rs, 613 F.3d 1229 (10th Cir. 2010), cert. denied, 131 S. Ct. 978 (2011). Also, the Ninth Circuit recently decided Centro Familiar Cristiano Buenas Nuevas v. City of Yuma and virtually adopted the Third Circuit's test. No. 09-15422, 2011 U.S. App. LEXIS 14247, at 22-23 (9th Cir. July 12, 2011) ("The city may be able to justify some distinctions drawn with respect to churches, if it can demonstrate that the less-than-equal-terms are on account of a legitimate regulatory purpose, not the fact that the institution is religious in nature. In this respect, our analysis is about the same as the Third Circuit's: we look to see if the church is 'similarly situated as to the regulatory purpose.' The Seventh Circuit, en banc, has refined this test to avoid inappropriate subjectivity by requiring equality with respect to 'accepted zoning criteria,' such as parking, vehicular traffic, and generation of tax revenue. That refinement is appropriate where necessary to prevent evasion of the statutory requirement, though it makes no practical difference in this case.” (footnotes omitted) (quoting Lighthouse Inst. for Evangelism, Inc. v. City of Long Branch, 510 F.3d 253, 266 (3d Cir. 2007); River of Life Kingdom Ministries v. Vill. of Hazel Crest, 611 F.3d 367, 373 (7th Cir. 2010) (en banc))). 
and summarize the circuit split and the tests put forth by the Eleventh, Third, and Seventh Circuits. This Comment will then argue against the Eleventh Circuit's textual interpretation, make the case that such an interpretation violates the First Amendment's Establishment Clause, and propose a test combining those used by the Third and Seventh Circuits.

\section{The DEVELOPMENT OF A NEW StANDARD: RLUIPA, ITS PURPOSE, AND ITS REQUIREMENTS}

The Religious Land Use and Institutionalized Persons Act grows out of the Supreme Court's Free Exercise Clause and, to a lesser extent, its Equal Protection Clause jurisprudence. ${ }^{15}$ This Section will highlight RLUIPA's background, explain its separate provisions and highlight their interaction, and explain Congress's intended role for RLUIPA.

\section{A. The Free Exercise Clause and the Development of RLUIPA}

The First Amendment to the U.S. Constitution contains two clauses governing state interaction with religion. ${ }^{16}$ The Free Exercise Clause prevents government from hindering a person's practicing the religion of his choosing; the Establishment Clause forbids the government from establishing or endorsing a state religion. ${ }^{17}$ The religion clauses conflict with one another. ${ }^{18}$ The state simultaneously must guarantee individuals the ability to practice their religion while avoiding promoting a specific religion—or religion generally—-too much. ${ }^{19}$ Somewhere between these

15. See Bram Alden, Comment, Reconsidering RLUIPA: Do Religious Land Use Protections Really Benefit Religious Land Users?, 57 UCLA L. REV. 1779, 1806 (2010) (stating that RLUIPA's substantial-burdens provision "is somewhat redundant in light of the Free Exercise Clause" and the equal-terms provision "is somewhat superfluous in light of the Equal Protection and Establishment Clauses”); see also Roman P. Storzer \& Anthony R. Picarello, Jr., The Religious Land Use and Institutionalized Persons Act of 2000: A Constitutional Response to Unconstitutional Zoning Practices, 9 GEO. MASON L. REV. 929, 930 (2001) (stating that RLUIPA protects land uses in much of the same way that they are already protected by the First and Fourteenth Amendments).

16. U.S. CONST. amend. I.

17. Id.; see also Patricia E. Salkin \& Amy Lavine, The Genesis of RLUIPA and Federalism: Evaluating the Creation of a Federal Statutory Right and Its Impact on Local Government, 40 URB. LAW. 195, 196 (2008) ("The religion clauses of the First Amendment . . . simultaneously forbid the government from establishing religion and from prohibiting its free exercise ....”).

18. See Cutter v. Wilkinson, 544 U.S. 709, 719 (2005) (noting that the Free Exercise and Establishment Clause “often exert conflicting pressures”) (citing Locke v. Davey, 540 U.S. 710, 718 (2004); Walz v. Tax Comm’n of N.Y.C., 397 U.S. 664, 668-69 (1970)).

19. See Estate of Thornton v. Caldor, Inc., 472 U.S. 703, 708 (1985) ("Under the Religion 
clauses stands the purported wall separating church and state. But for those who point to this wall to justify eliminating religion from public life, it will be disappointing to learn that this wall has never been as tall or sturdy as they wish. For example, the reverse side of the Great Seal of the United States, above an unfinished pyramid, proclaims the nation's second motto: Annuit Coeptis, which means "God (or Providence) has favored our undertakings." ${ }^{20}$ Before school each morning, most public school children pledge allegiance to the United States as "one nation, under God."21 Thus, it is clear that the state may help-often referred to as "accommoda[ting]"22 - the free exercise of religion to some degree without violating the Establishment Clause. What is not clear is when accommodation morphs into establishment.

For the past half century, the Supreme Court has engaged in an ongoing battle with Congress and state legislatures to determine how much a state may accommodate religion under the Free Exercise Clause without violating the Establishment Clause. The legislative bodies have consistently increased protection for religious exercise. ${ }^{23}$ The Supreme Court, on the other hand, has actively policed the outer limits of federal and state legislative power and reconciled the competing purposes of the First Amendment's religion clauses. ${ }^{24}$ RLUIPA is just the latest salvo in this ongoing and complicated clash as each institution tries to determine the proper dimensions of the wall between church and state. ${ }^{25}$

The Free Exercise Clause's modern treatment began in 1963 with the landmark case Sherbert v. Verner. ${ }^{26}$ In Sherbert, the Supreme Court

Clauses, government must guard against activity that impinges on religious freedom, and must take pains not to compel people to act in the name of any religion.”).

20. JOHN MEACHAM, AMERICAN GOSPEL: GOD, THE FOUNDING FATHERS, AND THE MAKING OF A NATION 81 (2006) (internal quotation marks omitted).

21. W. Va. State Bd. of Educ. v. Barnette, 319 U.S. 624, 642 (1943) (holding that the state may not compel students to pledge allegiance).

22. Cutter, 544 U.S. at 722.

23. See Sarah Keeton Campbell, Note, Restoring RLUIPA's Equal Terms Provision, 58 DUKE L.J. 1071, 1073, 1076-77 (2009) (highlighting the history of the Free Exercise jurisprudence that led to RLUIPA); see also Cutter, 544 U.S. at 714 ("RLUIPA is the latest of long-running congressional efforts to accord religious exercise heightened protection from government-imposed burdens, consistent with this Court's precedents.”).

24. See Cutter, 544 U.S. at 714.

25. See id.

26. 374 U.S. 398 (1963); see also Anthony Lazzaro Minervini, Comment, Freedom from Religion: RLUIPA, Religious Freedom, and Representative Democracy on Trial, 158 U. PA. L. REV. 571, 578 (2010). 
applied strict scrutiny to laws that burdened religious exercise. ${ }^{27}$ Strict scrutiny mandates that the government may not substantially burden religious exercise unless it can demonstrate that the burden furthers a compelling governmental interest and is the least restrictive means of furthering that interest. ${ }^{28}$ Typically, courts invalidate laws that are subject to strict scrutiny. ${ }^{29}$ Despite decreeing that it would apply strict scrutiny to laws burdening religion, the Court rarely used this test to invalidate these laws that hindered religious practice and "generally sided with the government when individuals claimed that laws infringed their free exercise of religion."30

In 1990, in Employment Division v. Smith, ${ }^{31}$ the Supreme Court rejected Sherbert's rarely used strict scrutiny test for an analysis that focused on whether the law was facially neutral and generally applicable. $^{32}$ In Smith, a criminal law prohibited possession of peyote, including possession by Native Americans for use during religious services. ${ }^{33}$ The Court declared that the Constitution tolerates laws that burden religion so long as those laws are neutral and generally applicable; religious observers, just like everyone else, must comply with the law. " ${ }^{34}$ " $\left.\mathrm{N}\right] \mathrm{o}$ matter how much a law burdens religious practices, it is constitutional ... so long as it does not single out religious behavior for punishment and was not motivated by a desire to interfere with religion." ${ }^{35}$ Smith is a seminal case, and a major point of contention regarding the proper interpretation of the equal-terms provision is how to deal with its mandate that cities may pass neutral and generally applicable laws that burden religious land use.

27. Sherbert, 374 U.S. at 403-09; see also ERWIN CHEMERINSKY, CONSTITUTIONAL LAW: PRINCIPLES AND POLICIES § 12.3.2.2, at 1252 (3d ed. 2006).

28. Sherbert, 374 U.S. at 406-09.

29. CHEMERINSKY, supra note $27, \S 9.1 .2$, at 671 .

30. Id. § 12.3.1, at 1248 .

31. 494 U.S. 872, 890 (1990), superseded by statutes, Religious Land Use and Institutionalized Persons Act of 2000, Pub. L. No. 106-274, 114 Stat. 803, as recognized in Cutter v. Wilkinson, 544 U.S. 709, 714-15 (2005) (acknowledging that RLUIPA supersedes Smith), and Religious Freedom Restoration Act of 1993, Pub. L. No. 103-141, 1993 U.S.C.C.A.N. (107 Stat.) 1488, invalidated in part by City of Boerne v. Flores, 521 U.S. 507, 534-35 (1997) (holding that Congress exceeded its Section 5 powers in enacting RFRA in response to Smith).

32. CHEMERINSKY, supra note $27, \S 12.3 .1$, at 1248.

33. 494 U.S. at 874.

34. See id. at 890.

35. CHEMERINSKY, supra note $27, \S 12.3 .1$, at 1248. 
After abandoning the application of strict scrutiny to facially neutral and generally applicable laws, the Supreme Court addressed whether strict scrutiny should apply to a law that is facially neutral but applied in a way that burdens religious exercise. In Church of the Lukumi Babalu Aye, Inc. v. City of Hialeah, the city passed a facially neutral law outlawing animal sacrifice after officials learned that followers of the Santeria religion, some of whose members engage in ritual animal sacrifice, planned to locate in the city. ${ }^{36}$ The law allowed local officials to exempt groups and activities from compliance, and they used this power to exempt virtually everyone else in the community from complying with the law except the Santeria members. ${ }^{37}$ The Court invalidated the law, holding that a facially neutral law may still face strict scrutiny like a non-neutral law, which virtually guarantees that it will be struck down, if it purposefully infringes upon a religious practice or is implemented in such a way that targets religion. ${ }^{38}$

After Smith and Lukumi effectively protected neutral, generally applicable laws from strict scrutiny, Congress expressed its disapproval of the diminished protection for religious exercise. ${ }^{39}$ It reacted by passing the Religious Freedom Restoration Act (RFRA) of 1993 that restored strict scrutiny for all laws that substantially burdened religious exercise. $^{40}$ Congress enacted RFRA under its power to remedy state violations of constitutional rights under Section 5 of the Fourteenth Amendment. In doing so, Congress defined for itself what the Free Exercise Clause permits. Through RFRA, Congress sought to expressly overrule Smith $^{41}$ and decide for itself the amount of protection the Constitution should give religious exercise.

36. 508 U.S. 520, 525-28 (1993); see also Minervini, supra note 26, at 579 (citing Lukumi, 508 U.S. at 525-29, 532).

37. 508 U.S. at 536, 543 (discussing the different exemptions the law provided).

38. Id. at 533 (stating that "if the object of a law is to infringe upon or restrict practices because of their religious motivation, the law is not neutral, and it is invalid unless it is justified by a compelling interest and is narrowly tailored to advance that interest” (citation omitted)).

39. Religious Freedom Restoration Act (RFRA) of 1993, Pub. L. No. 103-141, 1993 U.S.C.C.A.N. (107 Stat.) 1488, invalidated in part by City of Boerne v. Flores, 521 U.S. 507 (1997).

40. Boerne, 521 U.S. at 515-16 (reciting RFRA's requirements).

41. See Marci A. Hamilton, Federalism and the Public Good: The True Story Behind the Religious Land Use and Institutionalized Persons Act, 78 IND. L.J. 311, 343-44 (2003) ("From the viewpoint of the members of Congress, RFRA was a law aimed at the Supreme Court, with an incidental and constitutionally irrelevant effect on the states.”). 
Four years after Congress enacted RFRA, the Supreme Court struck it down in City of Boerne v. Flores. ${ }^{42}$ Rebuking Congress for acting beyond the scope of its Section 5 powers, the Court stated that "RFRA contradicts vital principles necessary to maintain separation of powers and the federal balance." 43 RFRA was not merely "remedial, preventative legislation" addressing free exercise violations committed by the states that the Court had previously recognized. ${ }^{44}$ Rather, it was an attempt "to expand religious liberty and civil rights guarantees beyond what the Court interpreted the Constitution to require in Smith."45 Congress granted these additional, substantive rights at the expense of the states' ability to legislate in areas traditionally governed by state police powers, including local land-use laws. ${ }^{46}$

Congress, again, did not take the Court's reprimand sitting down. It quickly began work on legislation "to enhance the level of protection afforded religious freedom." 47 The House Judiciary Committee introduced two bills in two consecutive sessions of Congress, each entitled the Religious Liberty Protection Act (RLPA). ${ }^{48}$ RLPA, like RFRA, attempted to again reinstate strict scrutiny for all laws burdening religious exercise, but Congress used its Article I powers rather than its Section 5 powers. ${ }^{49}$ Each bill stalled in the Senate, ${ }^{50}$ forcing Congress to abandon strict scrutiny as the default test for all laws that burdened free exercise. ${ }^{51}$ But continued lobbying to expand protection in two specific areas, religious land uses and religious expression for those held in state custody, led to RLPA's transformation into the more limited and focused RLUIPA. $^{52}$

42. 521 U.S. at 536; see also Campbell, supra note 23, at 1078. Despite Boerne's holding, RFRA still applies to the federal government. Cutter v. Wilkinson, 544 U.S. 709, 715 n.2 (2005).

43. Boerne, 521 U.S. at 536.

44. Id. at 532 .

45. Hamilton, supra note 41, at 332.

46. Id. at 332-33.

47. Michael Paisner, Note, Boerne Supremacy: Congressional Responses to City of Boerne v. Flores and the Scope of Congress's Article I Powers, 105 COLUM. L. REV. 537, 541 (2005).

48. See H.R. 1691, 106th Cong. (1999); H.R. 4019, 105th Cong. (1997).

49. Hamilton, supra note 41, at 333-34.

50. See Kenneth G. Leonczyk, Jr., RLUIPA and Eminent Domain: How a Plain Reading of a Flawed Statute Creates an Absurd Result, 13 TEX. REV. L. \& PoL. 311, 326-27 (2009).

51. Paisner, supra note 47, at 543 (citing 146 Cong. Rec. S7774 (daily ed. July 27, 2000).

52. See Hamilton, supra note 41, at 334 (noting the lobbying efforts which transformed RLPA into RLUIPA). 
Thus, RLUIPA targets two areas: laws pertaining to religious land uses and laws relating to religious exercise by institutionalized persons. ${ }^{53}$ RLUIPA's land-use provisions are organized into two sections: the substantial-burdens section and the discrimination-and-exclusion section. $^{54}$ The substantial-burdens section contains the substantialburden provision that states:

No government shall impose or implement a land use regulation in a manner that imposes a substantial burden on the religious exercise of a person, including a religious assembly or institution, unless the government demonstrates that imposition of the burden on that person, assembly, or institution-

(A) is in furtherance of a compelling governmental interest; and

(B) is the least restrictive means of furthering that compelling governmental interest. ${ }^{55}$

The substantial-burden provision is RLUIPA's strongest protection for religious land uses, but is not the subject of this Comment. The substantial-burdens section's compelling-interest requirement restores strict scrutiny for land-use regulations that substantially burden religious exercise.

The discrimination-and-exclusion section contains not only the equal-terms provision, but also a nondiscrimination provision that reads, "No government shall impose or implement a land use regulation that discriminates against any assembly or institution on the basis of religion or religious denomination." 56 The nondiscrimination provision forbids, just as the Free Exercise, Free Speech, and Equal Protection Clauses already prohibit, "[t]he most invidious form of free exercise violation," which "is discrimination among different religious denominations or sects" ${ }^{\text {"57 }}$ or discrimination based on religion.

RLUIPA parallels the Supreme Court's Free Exercise Clause jurisprudence and, considering that Clause's existing guarantees,

53. Leonczyk, supra note 50, at 321 (citing Religious Land Use and Institutionalized Persons Act (RLUIPA) of 2000, 42 U.S.C. §§ 2000cc-2000cc-5 (2000)).

54. 42 U.S.C. § 2000cc (2006).

55. Id. § 2000cc(a)(1).

56. Id. § 2000cc(b)(2).

57. Storzer \& Picarello, supra note 15, at 972. 
RLUIPA's protections are, in many ways, redundant. ${ }^{58}$ The substantialburdens section "enforces the Free Exercise Clause right to be free from state action that substantially interferes with the practice of religion without compelling justification." ${ }^{\text {"9 }}$ The discrimination-and-exclusion section attempts to "enforce[] the Free Exercise Clause right to be free from state action that discriminates on the basis of religion or religious practice, or discriminates among or between religions." ${ }^{\text {"0 }}$ Therefore, if a nonreligious assembly receives better treatment than a religious entity in a land-use decision, the religious entity could file suit alleging violations of the Free Exercise Clause, the substantial-burdens provision, the equalterms provision, the nondiscrimination provision, and possibly the Equal Protection Clause of the Fourteenth Amendment simultaneously. Such extensive litigation can be lengthy and costly, and some evidence suggests governments simply allow religious assemblies to locate rather than fight in court. ${ }^{61}$

\section{B. Congressional Intent}

Common land-use tools require local officials-boards, commissions, assessors-to make individualized assessments about proposed land uses that often allow some uses while denying other, similar ones. Variances allow landowners to escape restrictions if the use meets certain criteria. ${ }^{62}$ Many zoning codes list certain land uses as conditional uses, sometimes called special uses. ${ }^{63}$ These are not permitted as a matter of right, but local officials may allow them upon a determination that the use would not harm the surrounding area. ${ }^{64} \mathrm{~A}$ local governing body may amend a zoning law to allow for a use that it had previously denied. ${ }^{65}$ As should be clear, land-use regulation is often

58. Alden, supra note 15, at 1806.

59. River of Life Kingdom Ministries v. Vill. of Hazel Crest, 611 F.3d 367, 381 (7th Cir. 2010) (en banc) (Sykes, J., dissenting).

60. Id.

61. Alden, supra note 15, at 1808-09 (citing Peter Applebome, In the Character of a Village, It's Property vs. Religion, N.Y. TIMES, June 26, 2005, http://www.nytimes.com/2005/06/26/ nyregion/26towns.html?scp=1\&sq=in\%20the\%20character\%20of\%20a\%20village\&st=cse).

62. JOHN G. SPRANKLING, UNDERSTANDING PROPERTY LAW § 37.03 (2d ed. 2007).

63. Id. § 37.04 .

64. Id.

65. Id. § 37.02 . 
undertaken on an ad hoc, case-by-case basis, granting officials considerable discretion to allow and deny uses.

Congress was concerned that local officials were using this discretion to exclude religious land uses while allowing similar, secular uses. ${ }^{66}$ It makes some sense that local officials charged with managing a city would not be overly welcoming to churches, synagogues, and other houses of worship; these uses are typically not-for-profits, they do not generate large numbers of jobs or sales-tax revenue, and they can create a lot of traffic. With RLUIPA's land-use provisions, Congress intended to limit the "highly individualized and discretionary processes" that can be used to deny churches the ability to locate in a given district. ${ }^{67}$ Congress did not hold new hearings for RLUIPA. ${ }^{68}$ Instead, it relied on the hearings it had held for RLPA where it identified some instances where land-use laws burdened religious land use. ${ }^{69}$

In Cutter v. Wilkinson, the Supreme Court upheld RLUIPA's institutionalized-persons provision against an Establishment Clause challenge. $^{70}$ The Court recognized some accommodation of religion is permissible short of an Establishment Clause violation and that "'there is room for play in the joints"' between the Free Exercise Clause and the Establishment Clause. ${ }^{71}$ RLUIPA's institutionalized-persons provision, like the substantial-burden provision, codifies strict scrutiny by inserting the compelling-interest test. The applicable provision provides:

No government shall impose a substantial burden on the religious exercise of a person residing in or confined to an institution ... even if the burden results from a rule of general applicability, unless the

66. See 146 Cong. Rec. 16,698 (2000) (joint statement of Sens. Hatch and Kennedy) ("Churches in general, and new, small, or unfamiliar churches in particular, are frequently discriminated against on the face of zoning codes and also in the highly individualized and discretionary processes of land use regulation.”); see also Storzer \& Picarello, supra note 15, at 952 ("RLUIPA merely codifies the First Amendment's prohibition that the government, where it 'has in place a system of individual exemptions,' cannot 'refuse to extend that system to cases of 'religious hardship' without compelling reason."” (quoting Church of the Lukumi Babalu Aye, Inc. v. City of Hialeah, 508 U.S. 520, 537, 568 (1993))).

67. 146 CONG. REC. 16,698 (2000).

68. Hamilton, supra note 41, at 334. Unfortunately, "[t]he hearings for RLPA involving land use, which then became the sole legislative history for RLUIPA, did not even as a cursory matter take into account the law of land use.” Id. at 335.

69. Id. at 345 .

70. 544 U.S. 709, 720 (2005) (citing Bd. of Educ. of Kiryas Joel Vill. Sch. Dist. v. Grumet, 512 U.S. 687, 705 (1994)).

71. Id. at 719-20 (quoting Walz v. Tax Comm'n of N.Y.C., 397 U.S. 664, 669 (1970)). 
government demonstrates that imposition of the burden on that person-

(1) is in furtherance of a compelling governmental interest; and

(2) is the least restrictive means of furthering that compelling governmental interest. $^{72}$

The institutionalized-persons provision is an accommodation of religion because it provides more protection than Smith requires. ${ }^{73}$ The compelling-interest test measures that accommodation against the problems that it could cause for prison administrators by giving them sufficient leeway to advance the interests of maintaining order in their institutions. ${ }^{74}$ The Supreme Court has not ruled on the constitutionality of the equal-terms provision.

\section{THE LOWER COURTS’ INTERPRETATIONS OF RLUIPA’S EQUAL- TERMS PROVISION}

The equal-terms provision's straightforward language belies the disparate treatment that three circuit courts of appeals ${ }^{75}$ have given to its terms, procedural history, and conflict with the Establishment Clause. The Eleventh Circuit interprets the provision textually and will find a

72. 42 U.S.C. § 2000cc-1(a) (2006).

73. See Cutter, 544 U.S. at 714. "RLUIPA is the latest of long-running congressional efforts to accord religious exercise heightened protection from government-imposed burdens, consistent with this Court's precedents." Id. Even so, "the First Amendment's Free Exercise Clause does not inhibit enforcement of otherwise valid laws of general application that incidentally burden religious conduct[, and] the political branches could shield religious exercise through legislative accommodation.” Id. (citing Emp't Div. v. Smith, 494 U.S. 872, 890 (1990), superseded by statutes, Religious Land Use and Institutionalized Persons Act of 2000, Pub. L. No. 106-274, 114 Stat. 803, as recognized in Cutter v. Wilkinson, 544 U.S. 709, $714-15$ (2005) (acknowledging that RLUIPA supersedes Smith), and Religious Freedom Restoration Act of 1993, Pub. L. No. 103-141, 1993 U.S.C.C.A.N. (107 Stat.) 1488, invalidated in part by City of Boerne v. Flores, 521 U.S. 507, 53435 (1997) (holding that Congress exceeded its Section 5 powers in enacting RFRA in response to Smith)).

74. Id. at 722 .

75. The Ninth Circuit ruled shortly before publication of this Comment that it would apply basically the same test as the Third Circuit, but would use the Seventh Circuit's test where appropriate. Centro Familiar Cristiano Buenas Nuevas v. City of Yuma, No. 09-15422, 2011 U.S. App. LEXIS 14247, at *22 (9th Cir. July 12, 2011) ("In this respect, our analysis is about the same as the Third Circuit's: we look to see if the church is 'similarly situated as to the regulatory purpose.’” (quoting Lighthouse Inst. for Evangelism, Inc. v. City of Long Branch, 510 F.3d 253, 266 (3d Cir. 2007))). 
violation when a city treats any type of religious land use with any type of assembly on less-than-equal terms. ${ }^{76}$ That violation is then subject to strict scrutiny. ${ }^{77}$ Finding a violation is much harder in the Third and Seventh Circuits, but each circuit imposes strict liability, rather than strict scrutiny, to violations. ${ }^{78}$ Though these two circuits' tests differ slightly, at the core of each sits the so-called similarly situated requirement. The similarly situated requirement forces a religious assembly to show that it was treated on less-than-equal terms than a similar or comparable assembly, not simply any assembly. ${ }^{79}$ The Eleventh Circuit's textual interpretation is now in jeopardy as circuit and district courts around the country see its possible conflict with the Establishment Clause and the problems that it causes for municipalities.

\section{A. The Eleventh Circuit}

The Eleventh Circuit has treated the equal-terms provision with considerable depth, ${ }^{80}$ but no other circuit follows its interpretation. In Midrash Sephardi, Inc. v. Town of Surfside, a city ordinance excluded churches and synagogues from a business district but allowed private social, educational, and recreational nonprofit clubs. ${ }^{81}$ Two synagogues leased space in an area zoned for businesses, but only one applied for a special-use permit to use the space for religious purposes. ${ }^{82}$ The city denied the application and sought an injunction against each for the use of the spaces as synagogues. ${ }^{83}$ The city argued that excluding religious land uses was necessary to "invigorate the business district" as it was crucial to the city's "tax base, job base, and servicing the needs of

76. See Midrash Sephardi, Inc. v. Town of Surfside, 366 F.3d 1214, 1229, 1235 (11th Cir. 2004). According to the Eleventh Circuit, the equal-terms provision "lacks the 'similarly situated' requirement usually found in equal protection analysis." Id. at 1229 (citing City of Cleburne v. Cleburne Living Ctr., 473 U.S. 432, 447-50 (1985)).

77. Id. at 1232 (citing Church of Lukumi Babalu Aye, Inc. v. City of Hialeah, 508 U.S. 520, 546 (1993)).

78. See Lighthouse, 510 F.3d at 269 (stating that something more than less-than-equal treatment is required for a violation); River of Life Kingdom Ministries v. Vill. of Hazel Crest, 611 F.3d 367, 370-71 (7th Cir. 2010) (en banc) (taking issue with both the Eleventh and Third Circuit approaches and suggesting objective, non-manipulable criteria for evaluating violations).

79. Lighthouse, 510 F.3d at 269.

80. See Minervini, supra note 26, at 589-90 (explaining that “[t]he Eleventh Circuit's construction of RLUIPA's Equal Terms provision is the most comprehensive we have").

81. 366 F.3d at 1219-20.

82. Id. at $1220-21$.

83. Id. at $1220,1222$. 
Surfside's residents." ${ }^{84}$ But the Eleventh Circuit found the city ordinance violated the equal-terms provision because synagogues and private clubs were both assemblies, and the private clubs were allowed while the synagogues were not. ${ }^{85}$

The Eleventh Circuit adopted a strictly textual interpretation and incorporated dictionary definitions for the terms "assembly" and "institution," which RLUIPA neglected to define. ${ }^{86}$ The court defined "assembly" as either "“a company of persons collected together in one place [usually] and usually for some common purpose ${ }^{\text {’,87 }}$ or, in slightly different terms, “'[a] group of persons organized and united for some common purpose.”, 88 In the same manner, the court defined "institution” as either "'an established society or corporation: an establishment or foundation esp. of a public character"”,89 or, similarly, “'[a]n established organization, esp. one of a public character."”90 The Eleventh Circuit's test to find a violation is essentially two-fold. First, the court must determine if the religious land use "qualifies as an 'assembly or institution." ",1 If it does, then the court must look at the district to see "whether the governmental authority treats [the religious land use] differently than a nonreligious assembly or institution." 92 The court declined to adopt the similarly situated requirement it identified in the Supreme Court's Equal Protection Clause analysis and adopted by the Third and Seventh Circuits. ${ }^{93}$ Although the equal-terms provision, the court stated, "has the 'feel' of an equal protection law, [the text] lacks the 'similarly situated' requirement usually found in equal protection analysis." $" 94$

Even though strict scrutiny is not mentioned in the equal-terms provision, the Eleventh Circuit applies it to violations because that is the

\footnotetext{
84. Id. at $1221-22$.

85. Id. at 1231.

86. See id. at $1230-31$.

87. Id. at 1230 (quoting WEBSTER's 3D NEW INT'L UNABRIDGED DiCTIONARY 131 (1993)).

88. Id. (quoting BLACK's LAW DiCTIONARY 111 (7th ed. 1999)).

89. Id. at 1230 (quoting WEBSTER'S 3D NEW INT'L UNABRIDGED DiCTIONARY 1171 (1993)).

90. Id. at 1231 (alteration in original) (quoting BLACK’s LAW DiCTIONARY 801 (7th ed. 1999)).

91. Id. at 1230 (quoting 42 U.S.C. § 2000cc(b)(1) (2006)).

92. Id. (citing § $2000 \mathrm{cc}(\mathrm{b})(1))$.

93. See id. at 1230 (discussing the similarly situated requirement relied on by the district court and rejecting it).

94. Id. at 1229 (citing City of Cleburne v. Cleburne Living Ctr., 473 U.S. 432, 447-50 (1985)).
} 
level of review imposed on Free Exercise Clause violations. ${ }^{95}$ Thus, the court held that the law at issue in Midrash failed strict scrutiny because it was not narrowly tailored to promote its proffered interest. ${ }^{96}$ Specifically, the city excluded noneconomic religious assemblies but did not exclude noneconomic secular assemblies even though the secular assemblies similarly failed to promote "retail synergy." the Third and the Seventh Circuits would have reached the same result, but with a different methodology. ${ }^{98}$

Another important Eleventh Circuit case is Konikov v. Orange County. ${ }^{99}$ In Konikov, the plaintiff was a rabbi and the head of a local Orthodox Judaism organization. ${ }^{100}$ He held weekly meetings and Torah study in his home. ${ }^{101}$ The home was in a residential district that permitted, among other uses, family day cares, but required a special-use permit for religious uses and day-care centers. ${ }^{102}$ The county found that the use of his house for religious purposes violated the zoning ordinance, issued Code Violation Notices, and, ultimately, placed a lien on his property. ${ }^{103}$

The rabbi argued that the county violated the equal-terms provision twice. ${ }^{104}$ First, he argued that the zoning law facially violated the equalterms provision by forcing him to get a permit when other assemblies did not need one. ${ }^{105}$ The Eleventh Circuit found a potential violation-the county allowed day-care centers, which are assemblies, to locate while denying the right to religious assemblies. ${ }^{106}$ But the law did not facially violate the equal-terms provision because the violation passed strict

95. Id. at $1231-32$.

96. Id. at 1235.

97. See id. (noting that "private clubs and lodges endanger Surfside's interest in retail synergy as much or more than churches and synagogues").

98. See infra Parts III.B-C.

99. 410 F.3d 1317 (11th Cir. 2005) (per curiam).

100. Id. at 1320, 1320 n.2 (citing Arthur Green \& Shaul Magid, Hasidism: Habad Hasidism, in ENCYCLOPEDIA OF RELIGION (Lindsay Jones ed., 2d ed. 2005)).

101. Id. at 1320.

102. Id. (noting that "family day care operations" and "day care centers" are not the same under the challenged ordinance).

103. Id. at $1320-21$.

104. Id. at 1324.

105. Id. at $1324-27$.

106. Id. at $1326-27$. 
scrutiny-it was narrowly tailored to advance the compelling government interest of "protecting choice in the context of the family."107

Second, the rabbi argued that if the law was facially neutral, it nonetheless violated the equal-terms provision as applied to him because the county selectively enforced it against religious meeting places but not against secular meeting places. ${ }^{108}$ The court agreed. ${ }^{109}$ The law distinguished between social or family purposes, on the one hand, and religious purposes on the other. ${ }^{110}$ Cub scouts or dinner groups that met with the same frequency and number of attendees as the rabbi's religious meetings would be allowed, while the rabbi's gatherings would not be. ${ }^{111}$ The court held that because the only difference between allowed and disallowed uses was the religious motivation, the code targeted religious land uses as applied to the rabbi. ${ }^{112}$

The rabbi could have pursued remuneration under the Equal Protection Clause if he could show the discrimination was intentional. ${ }^{113}$ The main difference, it seems, between the Equal Protection Clause and equal-terms provision is that the equal-terms provision can be invoked even if the discrimination is not intentional. ${ }^{114}$ But when a plaintiff "produce[s] enough evidence to establish that a similarly situated secular institution has been treated more favorably under RLUIPA's equal terms provision, such evidence would provide strong support to an intentional discrimination allegation under the Equal Protection Clause.”115

In Primera Iglesia Bautista Hispana of Boca Raton, Inc. v. Broward County, ${ }^{116}$ the Eleventh Circuit expanded and clarified its jurisprudence relating to the equal-terms provision. ${ }^{117}$ The court identified three possible ways the equal-terms provision can be violated. First, a law may facially discriminate between religious and nonreligious

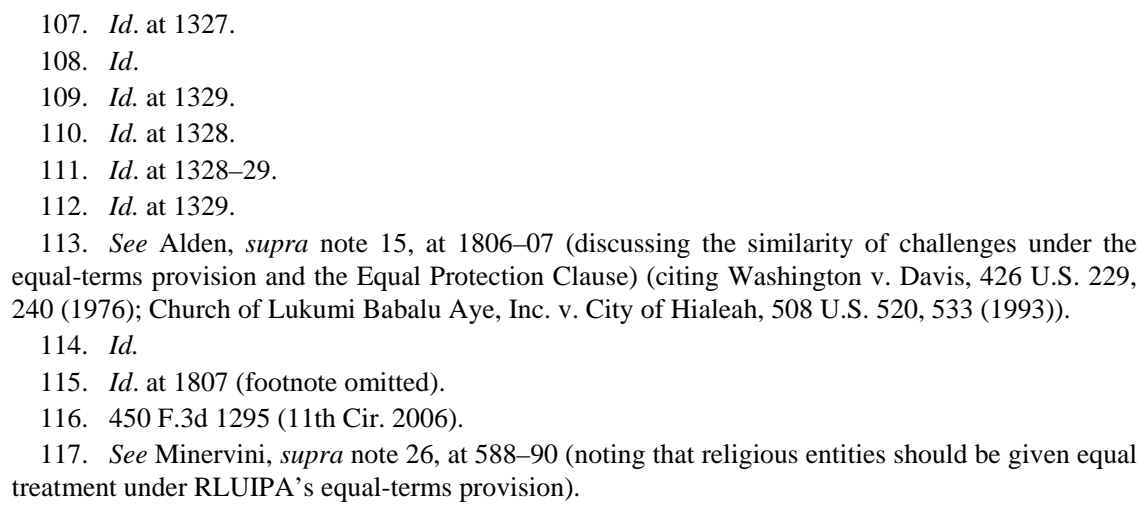


assemblies. ${ }^{118}$ This situation arose in Midrash when the city facially violated the equal-terms provision by excluding churches and synagogues but not private social clubs. ${ }^{119}$ Second, a facially neutral law can be drafted purposefully and carefully to burden only religious assemblies and institutions. ${ }^{120}$ This is commonly referred to as gerrymandering, and had the equal-terms provision been around when Lukumi was decided, that ordinance would have resulted in a violation of this manner. ${ }^{121}$ Third, a facially neutral statute can be selectively and discriminatorily applied so as to target a religious assembly or conduct while exempting nonreligious ones. ${ }^{122}$ Under this option, the Eleventh Circuit requires that the plaintiff show that a similarly situated nonreligious assembly received different treatment under the law at issue. ${ }^{123}$ This type of violation arose in Konikov when the city discriminatorily applied a facially neutral zoning code to keep religious assemblies out of the district while allowing similar secular assemblies. ${ }^{124}$

\section{B. The Third Circuit}

The Third Circuit disavowed the Eleventh Circuit's textual approach and became the first circuit to make the case for the similarly situated requirement. In Lighthouse Institute for Evangelism, Inc. v. City of Long Branch, a city excluded religious uses from its downtown commercial district, but it allowed, among other uses, assembly halls in the district. ${ }^{125}$ The church purchased property and applied for a zoning permit to use its property for religious purposes; the city denied the application. ${ }^{126}$ The church then sued the city, alleging a number of constitutional violations as well as violations of the equal-terms and substantial-burdens provisions. ${ }^{127}$ The church lost at the district court level. ${ }^{128}$ But as that

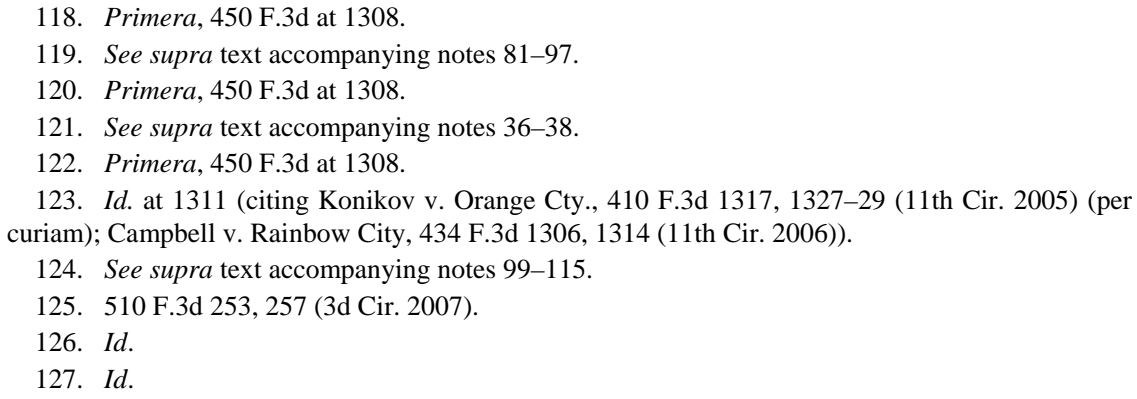


litigation made its way through the appellate courts, the city amended the zoning code at issue in the pending litigation. ${ }^{129}$ It adopted a redevelopment plan that de-listed assembly halls as a permitted use, continued to deny religious land uses, and prohibited any new use not specifically listed. ${ }^{130}$ The redevelopment plan's regulatory purpose was to create a " "vibrant' and 'vital' downtown residential community" out of the " 'underdeveloped and underutilized"” commercial district in order to strengthen trade, increase revenues, and create jobs by attracting business. $^{131}$

The Third Circuit divided its analysis into post-amendment and preamendment periods. The court upheld the church's exclusion from the district after the amendment was enacted because the church was "not similarly situated to the other allowed assemblies with respect to the aims of the Plan.”" ${ }^{32}$ The assemblies allowed in the district after the amendment - theaters, cinemas, arts centers, and others that generate income and encourage foot traffic ${ }^{133}$ - did not negatively impact the district's economic revitalization as a church would. ${ }^{134}$

Though the city's post-amendment plan did not violate the equalterms provision, its pre-amendment plan did. ${ }^{135}$ By permitting assembly halls and denying churches, the city treated a religious assembly on lessthan-equal terms with another assembly that similarly affected the district's regulatory purpose; this violates the equal-terms provision for two reasons. ${ }^{136}$ First, the city did not provide a regulatory purpose for the district before the amendment, so there was no way for the court to determine how each assembly would affect the district. ${ }^{137}$ Second, and most importantly, even if there had been a stated regulatory purpose, the city would be unable to show "why a church would cause greater harm to regulatory objectives than an 'assembly hall' that could be used for unspecified meetings.”138

128. Id.

129. Id. at 258.

130. Id.

131. Id. (quoting the Broadway Redevelopment Plan).

132. Id. at 270 .

133. Id. at 272 .

134. Id. at 270-71.

135. Id. at 272-73.

136. Id. at 272 .

137. Id.

138. Id. 
The Third Circuit adopted the similarly situated requirement because it felt using the requirement was the best way to fulfill Congress's intent to incorporate the Supreme Court's Free Exercise Clause jurisprudence into RLUIPA. ${ }^{139}$ After examining key Supreme Court cases as well as its own past cases, the court declared that under free exercise jurisprudence "[t]he impact of the allowed and forbidden behaviors must be examined in light of the purpose of the regulation." ${ }^{\text {"140 }}$ A neutral and generally applicable law, and thus permissible under Smith, does not become presumptively invalid "simply because it allows certain secular behaviors but not certain religious behaviors." 141 Additionally, if the "government permits secular exemptions to an otherwise generally applicable government regulation, the Free Exercise Clause requires that the government accord equal treatment to religion-based claims for exemptions that would have a similar impact on the protected interests." ${ }^{142}$ The court discussed Lukumi when justifying its conclusion that Free Exercise violations "hinge[] on a comparison of how it treats entities or behavior that have the same effect on its objectives."143 The law in Lukumi did not fail simply because it allowed animal slaughter for secular reasons but not for religious reasons. Rather, it failed because both religious and secular slaughter affected the city's regulatory goals in the same way, yet the city treated the two behaviors differently. ${ }^{144}$ Such "unequal treatment of equally detrimental behaviors is what caused the violation of the Free Exercise Clause." 145 Thus, the proper comparison for the Third Circuit is not between all religious assemblies and all secular assemblies regardless of their differences. Instead, the proper approach compares a religious assembly and an analogous secular assembly that similarly impact a regulation's aims. ${ }^{146}$

\footnotetext{
139. See id. at 264-68 (discussing the Free Exercise Clause’s interplay with RLUIPA).

140. Id. at 265 .

141. Id. at 264-65 (citing Emp’t Div. v. Smith, 494 U.S. 872, 890 (1990), superseded by statutes, Religious Land Use and Institutionalized Persons Act of 2000, Pub. L. No. 106-274, 114 Stat. 803, as recognized in Cutter v. Wilkinson, 544 U.S. 709, 714-15 (2005) (acknowledging that RLUIPA supersedes Smith), and Religious Freedom Restoration Act of 1993, Pub. L. No. 103-141, 1993 U.S.C.C.A.N. (107 Stat.) 1488, invalidated in part by City of Boerne v. Flores, 521 U.S. 507, 53435 (1997) (holding that Congress exceeded its Section 5 powers in enacting RFRA in response to Smith)).

142. Id. at 265.

143. Id. at 264-65.

144. Id. at 265 .

145. Id.

146. Id. at 266.
} 
The court further recognized that a broad, textual interpretation greatly interferes with local development. Here, a New Jersey state law prohibited liquor sales within 200 feet of religious assemblies. ${ }^{147}$ Even if the church agreed to waive its right to enforce the statute in this particular instance, the church would still retain discretion to enforce the statute against subsequent new licensees. ${ }^{148}$ This gives churches de facto veto power over new assemblies and undue control over the new entertainment district. ${ }^{149}$

In dissent, Judge Jordan criticized the similarly situated requirement. ${ }^{150}$ Judge Jordan noted that Congress did not include it in the plain text of the statute. ${ }^{151}$ He further argued that RLUIPA is not an attempt to enforce the Equal Protection Clause, which contains the similarly situated requirement, but rather the Free Exercise Clause, and grafting such a requirement onto the statute frustrates Congress's purpose. $^{152}$

Two other courts that have seemingly adopted the Third Circuit's test deserve treatment. The Tenth Circuit has not explicitly outlined or adopted a test to interpret the equal-terms provision. But in Rocky Mountain Christian Church v. Board of County Commissioners, a panel of the Tenth Circuit did not rebuke the district court for using the similarly situated requirement. ${ }^{153}$ The court decided the case using traditional Free Exercise Clause principles because the zoning law was "discriminatorily applied" to target the church. ${ }^{154}$ Whether this failure to criticize the district court will translate into an adoption of the similarly situated requirement remains to be seen.

In Centro Familiar Cristiano Buenas Nuevas v. City of Yuma, Judge Wake of the District of Arizona adopted the Third Circuit's test and effectively held that Smith provides an affirmative defense for disallowing a religious land use based upon a neutral and generally

\footnotetext{
147. Id. at 270 (citing N.J. STAT. ANN. § 33:1-76 (West 1994)).

148. Id. at 271.

149. Id.

150. Id. at 292-93 (Jordan, J., dissenting).

151. Id. at 293 (citing Vision Church United Methodist v. Vill. of Long Grove, 468 F.3d 975, 1002-03 (7th Cir. 2006)).

152. Id.

153. See 613 F.3d 1229, 1236 (10th Cir. 2010) (stating that "the district court properly instructed the jury that RMCC must establish 'that [the County] treated [RMCC] less favorably ... than [the County] treated a similarly situated nonreligious assembly or institution'” (alterations in original)).

154. Id. at $1237-38$.
} 
applicable law. ${ }^{155}$ "A zoning ordinance does not violate the equal terms provision, even if it permits some secular assemblies or institutions and excludes religious assemblies or institutions, so long as there is a neutral and generally applicable principle for doing so."156 Judge Wake felt that "Congress codified but did not exceed free exercise principles."157 In contrast, the substantial-burdens provision does exceed free exercise principles, and should be considered an accommodation, because it subjects a category of laws that had previously not been subject to strict scrutiny under Smith to strict scrutiny.

\section{The Seventh Circuit}

The Seventh Circuit cited the Eleventh Circuit without criticism until July 2010. ${ }^{158}$ But, as if outlining and analyzing this statute was not complicated enough, the Seventh Circuit, in an opinion by Judge Posner who had previously authored decisions favorably citing the Eleventh Circuit but without fully adopting its analysis, ${ }^{159}$ announced its own test. In an en banc hearing, the Seventh Circuit adopted the similarly situated requirement but shifted its focus from a district's regulatory purpose to a district's regulatory criteria. ${ }^{160}$ In River of Life, a small church wanted to relocate into a city's dilapidated downtown, which was zoned as a commercial district that excluded any new, noncommercial uses to encourage revitalization. ${ }^{161}$ When the city denied its entry, the church sued. ${ }^{162}$ The district court refused to enjoin enforcement of the zoning ordinance because the law treated similar assemblies-both the church and other new, noncommercial assemblies such as libraries and

155. 615 F. Supp. 2d 980, 995-96 (D. Ariz. 2010), rev'd, No. 09-15422, 2011 U.S. App. LEXIS 14247 (9th Cir. July 12, 2011).

156. Id. at 996.

157. Id. at 995 (citing Primera Iglesia Bautista Hispana of Boca Raton, Inc. v. Broward Cty., 450 F.3d 1295, 1308 (11th Cir. 2006)).

158. River of Life Kingdom Ministries v. Vill. of Hazel Crest, 611 F.3d 367, 369 (7th Cir. 2010) (en banc) (noting that the court "had cited Midrash without criticism but had not been centrally concerned with the interpretive issue presented in this case").

159. See Digrugilliers v. Consol. City of Indianapolis, 506 F.3d 612, 616 (7th Cir. 2007) (citing Midrash Sephardi, Inc. v. Town of Surfside, 366 F.3d 1214, 1227-31 (11th Cir. 2004)).

160. River of Life, 611 F.3d at 371 (stating that the equal-terms provision was imperfectly realized by the Third Circuit).

161. Id. at 368 .

162. Id. 
community centers - the same in relation to the regulatory criteria of the district. $^{163}$

The Seventh Circuit felt Congress's overriding goal for the equalterms provision was to promote equality between religious and nonreligious land uses. ${ }^{164}$ Equality, Judge Posner wrote, "except when used of mathematical or scientific relations, signifies not equivalence or identity but proper relation to relevant concerns."165 The equal-terms provision best fulfills its objective if it compares the city's treatment of different assemblies in relation to the district's objective and wellpublicized zoning criteria—commercial, residential, industrial, or some combination of the three-rather than a dictionary definition or a regulatory purpose that can be manipulated by local officials more easily than zoning criteria. ${ }^{166}$

The Seventh Circuit discussed the importance of zoning and land-use regulations at length. Segregating uses, the court observed, allows officials to create separate areas of a city "'to [e]nsure a better and more economical use of municipal services, such as schools, providing police protection, preventing and fighting fires, and better use of street facilities." "167 The city has every right to designate different areas for different uses to promote the general welfare, encourage rational development, and, ultimately, create safe cities. ${ }^{168}$ Not surprisingly, the Seventh Circuit's test reflects this deference.

In dissent, Judge Sykes forcefully advocated for a textual interpretation ${ }^{169}$ with a slight alteration in the definition of assembly. ${ }^{170}$ She disagreed that any similarly situated requirement exists in the Supreme Court's Free Exercise Clause jurisprudence, contending that the requirement is only a way to "ferret[] out" discriminatory intent from equal protection jurisprudence. ${ }^{171}$ To mollify concerns over a broad definition, she pressed for a nuanced definition of assembly. ${ }^{172}$ Bars,

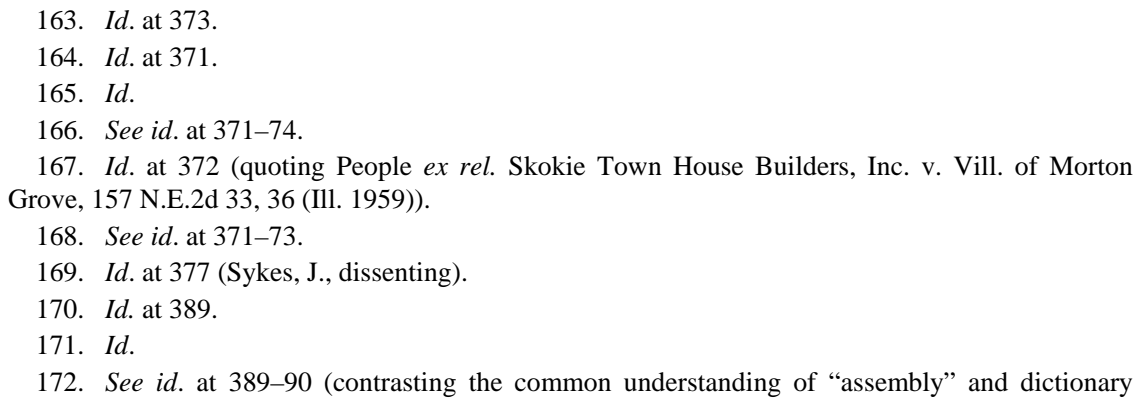


restaurants, health clubs, and other assemblies whose primary use is not simply to gather but to gather and perform another act-like having a drink or eating a meal-should not be considered assemblies for purposes of the equal-terms provision. ${ }^{173}$ Even though people "assemble for a common purpose" at these places, each lacks a "degree of group affinity, organization, and unity around a common purpose."174 This definition would lessen the number of comparators for a church to use, and, presumably, the test would find fewer violations.

\section{ANALYSIS AND PROPOSED APPROACH}

Each test will reach similar conclusions in run-of-the-mill cases disputing the equal-terms provision, but the test matters greatly in the borderline cases. All equal-terms provision tests are broken into two sections: the identification of a violation and the determination of the level of scrutiny to which the violation is subject. The Eleventh Circuit's approach - a textual interpretation of the violation and application of strict scrutiny to allow the government to escape the provision's mandates ${ }^{175}$ - may be the most workable test in practice. Allowing a textual interpretation to control is usually preferred. Also, it makes sense to conclude that since strict scrutiny is applied to free exercise challenges, it should apply to RLUIPA provisions as well. Unfortunately, the Eleventh Circuit's test simply does not do justice to the statute and will result in bizarre and unintended outcomes. This Section highlights three important cases and contends that the Eleventh Circuit's interpretation facially violates the Establishment Clause and will likely result in a successful as-applied challenge as well. Because the Eleventh Circuit's textual interpretation does not account for the burdens on nonbeneficiaries and improperly relies on strict scrutiny to save it, this test should be avoided in favor of the other tests that adopt the similarly situated requirement. Finally, this Section proposes merging the Third and Seventh Circuit tests.

definitions of "assembly").

173. See id. at 390.

174. Id.

175. See generally supra Part III.A. 


\section{A. The Eleventh Circuit's Textual Interpretation Results in a Facial Violation of the Establishment Clause}

Through RLUIPA's land-use provisions, Congress intended to "enforce the Free Exercise Clause rule against laws that burden religion

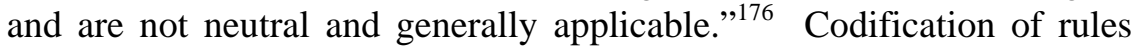
laid out in Supreme Court cases are not usually subject to successful constitutional challenges because they are considered "ffederal enforcements of federal rights." "'177 But the Eleventh Circuit's test does not simply codify existing guarantees. A textual interpretation extends protection beyond the bounds of free exercise rules and is therefore subject to a constitutional challenge. If the equal-terms provision codified the line of cases outlined in Part II, ${ }^{178}$ then cities would have an affirmative defense based on Smith - that is, a city could exclude a church or synagogue if it had a neutral and generally applicable reason for doing so. Without the equal-terms provision and RLUIPA's other land-use provisions, a religious assembly does not have an independent right to locate in a district that excludes it with a facially neutral and generally applicable zoning ordinance. ${ }^{179}$

The Eleventh Circuit's test is inconsistent with this approach. For example, if a city's redevelopment plan excludes any new, noncommercial uses to promote economic revitalization, as was the case in Lighthouse, ${ }^{180}$ but an existing school is located in the district, then the Eleventh Circuit's approach would allow a church and disallow a similar, secular use. A textual interpretation defeats the neutral and generally applicable law. Therefore, the argument that the equal-terms provision cannot be unconstitutional because it is just legislative enactment of free exercise rules laid out by the Supreme Court must fail because a textual interpretation actually defeats Smith's holding.

\footnotetext{
176. 146 Cong. REC. 16,699 (2000) (joint statement of Sens. Hatch and Kennedy). "Sections 2(b)(1) and (2) prohibit various forms of discrimination against or among religious land uses.” Id.; see supra Part II.A.

177. See Salkin \& Lavine, supra note 17, at 215 (quoting United States v. Maui Cnty., 298 F. Supp. 2d 1010, 1015 (D. Haw. 2003)).

178. See supra Part II.A.

179. Judge Wake made this point in Centro Familiar discussed in Part III.B. See supra text accompanying notes 155-56.

180. See Lighthouse Inst. for Evangelism, Inc. v. City of Long Branch, 510 F.3d 253, 258 (3d Cir. 2007).
} 
The fact that the Eleventh Circuit's interpretation extends protection beyond what has previously been allowed does not render the interpretation per se invalid in the slightest. Instead, the focus must shift to determine if a textual interpretation is a valid accommodation of religion beyond what the Free Exercise Clause requires but still short of what the Establishment Clause forbids. This Section argues that it is not.

The Supreme Court declared that RLUIPA is an attempt by Congress to accommodate religious practice beyond traditional free exercise principles but short of an unconstitutional endorsement. ${ }^{181}$ To pass muster, the accommodation must be neutral towards religion and may not "favor religion over secularism or one religion over others." 182 The essential test is whether the law simply accommodates religious exercise or, instead, favors religion to the point of a symbolic endorsement of religion over secularism. ${ }^{183}$ The Supreme Court has employed the "accommodation versus endorsement" test in a few important cases, but the context differed in each. ${ }^{184}$

In Cutter, RLUIPA's institutionalized-persons provision faced an Establishment Clause challenge. ${ }^{185}$ This provision prohibits states from imposing substantial burdens on religious exercise of those held in state custody "unless the burden furthers 'a compelling governmental interest,' and does so by 'the least restrictive means." "186 This so-called

181. Cutter v. Wilkinson, 544 U.S. 709, 720 (2005).

182. CHEMERINSKY, supra note 27, § 12.2.1, at 1193. There is no reason to think that RLUIPA will favor one religion over another because the statute makes no mention of specific religions, just religion in general.

183. See id. § 12.2.1, at 1193-96. "Under [the neutrality theory] approach, the government violates the establishment clause if it symbolically endorses a particular religion or if it generally endorses either religion or secularism.” Id. §12.2.1, at 1194. The Court will likely employ the neutrality theory because it did so in Cutter. See Cutter, 544 U.S. at 719 (stating the constitution obligates “neutrality” (quoting Sherbert v. Verner, 374 U.S. 398, 422 (1963) (Harlan, J., dissenting)) (internal quotation marks omitted)).

184. The Court will not employ the Lemon Test outlined in Lemon v. Kurtzman, 403 U.S. 602, 612-13 (1971). Because it declined to use Lemon to evaluate one section of RLUIPA, it will likely not employ it to evaluate another section of the same statute. Cutter, 544 U.S. at 717-18 n.6. Two cases, however, both cited in Cutter, do rely on Lemon's second prong-declaring that a law's principal or primary effect must not advance or inhibit religion-to evaluate whether an accommodation violates the Establishment Clause. Cutter, 544 U.S. at 719 (citing Corp. of the Presiding Bishop of the Church of Jesus Christ of Latter-Day Saints v. Amos, 483 U.S. 327 (1987)); id. at 720 (citing Estate of Thornton v. Caldor, Inc., 472 U.S. 703 (1985)). In any event, these tests are virtually the same: the law "must not symbolically endorse religion or a particular religion." CHEMERINSKY, supra note 27, § 12.2.3, at 1204 (citing Bd. of Educ. of Westside Cmty. Schs. v. Mergens, 496 U.S. 226, 249-53 (1990) (plurality opinion)).

185. 544 U.S. at 713.

186. Id. at 712 (quoting 42 U.S.C. § 2000cc-1(a)(1)-(2) (2006)). 
compelling-interest test simply recodifies strict scrutiny for laws in this area. Laws that "alleviate[] exceptional government-created burdens on private religious exercise" will often result in a ruling that they accommodate and do not endorse. ${ }^{187}$ The provision accomplished just this while accounting for the burdens it placed on the law's nonbeneficiaries so that it "[did] not override other significant interests." 188 For example, if allowing a Catholic inmate access to sacramental wine ${ }^{189}$ or providing sack lunches to Jewish or Muslim inmates to break a fast after nightfall ${ }^{190}$ would result in legitimate security concerns for the institution, then prison officials need not accommodate the prisoner's religious practice. ${ }^{191}$ The law helps religion, but not at the complete expense of prison officials' ability to manage an institution.

The law at issue in Estate of Thornton v. Caldor, Inc., however, did not toe this line as gingerly. ${ }^{192}$ In Thornton, a Connecticut law guaranteed every employee the right to take the day off of work on whatever day the employee decreed was his Sabbath. ${ }^{193}$ This accommodation violated the Establishment Clause because it advanced religion over all other interests. ${ }^{194}$ The law failed to account for the burdens it placed on its nonbeneficiaries - the employers and other employees-who were forced to conform to the religious practice without exception. ${ }^{195}$

In Corporation of the Presiding Bishop of the Church of Jesus Christ of Latter-Day Saints v. Amos, a section of Title VII of the 1964 Civil Rights Act exempted secular activities of religious organizations, such as

187. Id. at 720 (citing Bd. of Educ. of Kiryas Joel Vill. Sch. Dist. v. Grumet, 512 U.S. 687, 705 (1994)).

188. Id. at 722 .

189. Id. at 716 n.5 (citing Protecting Religious Freedom After Boerne v. Flores: Hearing Before the Subcomm. on the Constitution of the H. Comm. on the Judiciary, 105th Cong. 58-59 (1998) (prepared statement of Donald W. Brooks, Reverend, Diocese of Tulsa, Okla.)).

190. Id. (citing Protecting Religious Freedom After Boerne v. Flores: Hearing Before the Subcomm. on the Constitution of the H. Comm. on the Judiciary, 105th Cong. 39 (1998) (statement of Isaac M. Jaroslawicz, Dir. of Legal Affairs, Aleph Inst.)).

191. Id. at 725 .

192. 472 U.S. 703, 708-09 (1985).

193. Id.

194. Id. at 709-11.

195. See id. at 708-09 ("The State has thus decreed that those who observe a Sabbath any day of the week as a matter of religious conviction must be relieved of the duty to work on that day, no matter what burden or inconvenience this imposes on the employer or fellow workers.”). 
church-affiliated nonprofits, from the prohibition against discrimination in employment based on religion. ${ }^{196}$ The exemption was a permissible legislative accommodation because it "alleviate[d] significant governmental interference with the ability of religious organizations to define and carry out their religious missions." ${ }^{\text {"97 }}$ In his concurring opinion, Justice Brennan acknowledged that the exemption burdened employees because the exemption justified discrimination if an employee failed to conform to the organization's religious practices and beliefs. ${ }^{198}$ But in this "confrontation between the rights of religious organizations and those of individuals," 199 the ability of the religious organization to define and carry out its mission trumped the burden on the individual. ${ }^{200}$ Had the Court ruled differently, it would have effectively mandated the hiring practices of religious organizations and thus violated one of the Court's primary goals of the Free Exercise Clause-noninterference with the religious beliefs of Americans. ${ }^{201}$

Though each of these cases is different, rules governing the permissible scope of an accommodation are relatively clear. Government has more leeway to accommodate religion when alleviating government-created burdens - such as, for example, exempting religion from compliance with otherwise valid laws - than when it simply provides religion with an outright benefit. ${ }^{202}$ But an accommodation that fails to account for its impact on those that do not benefit from the law will "founder on [the] shoals" of the Court's previous decisions and violate the Establishment Clause by advancing religion over all other interests. ${ }^{203}$

RLUIPA's institutionalized-persons provision fits within the hazy, gray interior between the First Amendment's religious clauses because it alleviates government-created burdens while accounting for the law's

\footnotetext{
196. 483 U.S. 327,329 (1987).

197. Id. at 335 .

198. Id. at 340 (Brennan, J., concurring).

199. Id.

200. See id. at 342-43.

201. Cutter v. Wilkinson, 544 U.S. 709, 719 (2005).

202. See CHEMERINSKY, supra note 27, § 12.2.3, at 1205 ("The difference between Thornton and Amos is that the latter involved an exemption ... whereas the former ... provided a benefit.... The Court found that the latter was permissible, but that the former was the government advancing religion through its own activities and influence.”).

203. Cutter, 544 U.S. at 720.
} 
burdens on its nonbeneficiaries. ${ }^{204}$ The Eleventh Circuit's textual interpretation of the equal-terms provision, however, does not meet this test. Although it alleviates government-created burdens, the Eleventh Circuit's test fails to account for the burdens it places on nonbeneficiaries because cities and municipalities cannot escape its requirements even when there are valid reasons to exclude them. Without the "strict scrutiny' gloss" that the Eleventh Circuit adds to its interpretation, ${ }^{205}$ its test is dangerously reminiscent of that used by the Thornton Court to strike down a law that singled out religious practices for a benefit without considering the law's effect on employers. ${ }^{206}$ In Midrash, where the Eleventh Circuit outlined its test, the court completely overlooked the requirement that an ordinance providing accommodations must account for its burdens and, rather, relied only on the fact that the government may help religious organizations advance religion by alleviating burdens. ${ }^{207}$

The Eleventh Circuit and supporters of its interpretation will contend that because it subjects violations to strict scrutiny, which allows a government to justify the violation, it clearly accounts for the law's burdens and brings the law squarely into the area between the religious clauses. But the problem with that argument is that strict scrutiny is itself improper. Since strict scrutiny is the only way the test accounts for its burdens, its removal renders the entire test invalid.

Substantively, strict scrutiny is unnecessary for two reasons. First, the equal-terms provision is a different creature than either the institutionalized-persons provision or the substantial-burdens provision. It does not grow specifically out of the Smith, Lukumi, and City of Boerne Free Exercise Clause line of cases as provisions that reinstate strict scrutiny do; it is a wholly new creation provided as an additional and complementary protection to RLUIPA's substantial-burdens provision. Because it is a new creation, the text simply does not contain strict scrutiny ${ }^{208}$ - the central aspect of the battle between Congress and the Court from that line of cases.

204. Id. (citing Estate of Thornton v. Caldor, Inc., 472 U.S. 703 (1985)).

205. River of Life Kingdom Ministries v. Vill. of Hazel Crest, 611 F.3d 367, 370 (7th Cir. 2010) (en banc) (commenting on the Eleventh Circuit's approach); see also infra notes 208-10 and accompanying text (arguing strict scrutiny is improper).

206. Thornton, 472 U.S. at 708-09.

207. See Midrash Sephardi, Inc. v. Town of Surfside, 366 F.3d 1214, 1241 (11th Cir. 2004).

208. River of Life, 611 F.3d at 370-71. 
Second, statutes must be read as a whole, and RLUIPA's structure shows that Congress did not intend for strict scrutiny anywhere in the application of the equal-terms provision. As shown above, Congress codified strict scrutiny in two other places within the same statute but explicitly declined to do so in the equal-terms provision. In fact, the substantial-burdens provision should be considered the focal point of the land-use section since it was over this provision that the Supreme Court and Congress fought, and any violation of the equal-terms provision will also amount to a substantial burden. This lends support to the conclusion that Congress did not want strict scrutiny for equal-terms violations. ${ }^{209}$

Critics should question the rationale behind adopting the similarly situated analysis from outside the text and rejecting strict scrutiny. Again, the fact that Congress chose not to include strict scrutiny within the equal-terms provision speaks volumes. It had been engaged in a highly lobbied, ${ }^{210}$ fifty-year struggle with the Supreme Court concerning strict scrutiny and easily could have included it throughout the statute if it wanted. Further, the similarly situated requirement mimics strict scrutiny by examining whether the law is narrowly tailored. Similarly situated analysis, just like narrowly tailored analysis, examines whether the law affects religious and nonreligious assemblies equally in relation to its goal.

\section{B. The Eleventh Circuit's Textual Interpretation May Result in an As- Applied Violation of the Establishment Clause}

The analysis above contends that the Eleventh Circuit's textual interpretation of the equal-terms provision may facially violate the Establishment Clause. But this is not the only way the equal-terms provision may run afoul of the Establishment Clause. The large number of land-use devices makes an as-applied Establishment Clause challenge unavoidable. It is easy to imagine a situation in which a textual approach would lead to an as-applied Establishment Clause violation, while a test

\footnotetext{
209. Matthias Kleinsasser, Note, RLUIPA's Equal Terms Provision and the Split Between the Eleventh and Third Circuits, 29 REV. LITIG. 163, 173 (2009) ("Noting that RLUIPA's Substantial Burdens section codifies strict scrutiny by its plain language while the Discrimination and Exclusion section does not, the court concluded that Congress did not intend to incorporate strict scrutiny into the Equal Terms provision.” (citing Lighthouse Inst. for Evangelism, Inc. v. City of Long Branch, 510 F.3d 253, 269 (3d Cir. 2007))).

210. See Hamilton, supra note 41, at 334 (noting the activities of a number of groups lobbying for and against RLPA).
} 
incorporating the similarly situated requirement would not. For example, imagine that Imaginary City zoned an area as strictly commercial and did not allow any noncommercial uses. The regulatory purpose is to increase tax revenues and encourage foot traffic for businesses. Two entities-a small church and a small, secular nonprofit-apply for a special-use permit to allow for noncommercial uses. Both organizations are tax-free entities that create no jobs, generate no foot traffic, and attract the same number of people. A movie theater and a bowling alley are currently located in the zone and classify as assemblies under a textual interpretation because each falls within the dictionary definition of a place where people "“collect[] together in one place... for some common purpose.,"211

If Imaginary City were in the Eleventh Circuit, the city would be forced to welcome the church, but it would still be free to exclude the nonprofit. Further, even if the Eleventh Circuit keeps strict scrutiny, it is unlikely that "promoting economic development" would suffice as a compelling interest. ${ }^{212}$ The Eleventh Circuit, in essence, requires the city to prioritize the church over both its developmental priorities and secular land uses.

If Imaginary City were in the Third or Seventh Circuits, the result would be different. Both entities could properly be denied. The Third Circuit would permit denial because neither organization generates tax revenue or foot traffic. The Seventh Circuit would likewise permit denial because neither organization is a commercial organization, and only commercial organizations are allowed. Either test accounts for the burdens on the locality and treats similar organizations equally. In his concurring opinion in River of Life, however, Judge Manion took issue with this argument. He stated the "government may grant exemptions to religious observers without violating the Establishment Clause.”"13 This is surely true. The ability for governments to choose to grant exemptions, however, is wholly different than Congress forcing a municipality to grant exemptions for religious land uses while denying similarly situated secular land uses. In fact, such treatment may even

211. Midrash, 366 F.3d at 1230 (quoting WeBsteR's 3D NEW INT'L UNABRIDGED DictionARY 131 (1993)).

212. See Storzer \& Picarello, supra note 15, at 962-67 (discussing trends in the identification and recognition of "compelling interests").

213. River of Life, 611 F.3d at 376 (Manion, J., concurring) (emphasis added) (citing Wallace v. Jaffree, 472 U.S. 38, 82 (1985) (O’Connor, J., concurring)). 
give the similarly situated secular assembly grounds to sue under an Equal Protection Clause theory if it can show that a distinction between religious uses and nonreligious uses invokes a suspect classification. ${ }^{214}$

\section{The Case for Avoiding a Textual Interpretation}

After concluding that a textual interpretation of the equal-terms provision will, in the least, conflict with the Establishment Clause and, at the most, result in its invalidation, the remaining question considers the appropriate interpretation of the provision. "'The cardinal principle of statutory construction ... is to save and not to destroy.",215 Since before Marbury v. Madison, ${ }^{216}$ courts have employed the avoidance canon, called "the preeminent canon of federal statutory construction" by one commentator, to save statutes from unconstitutionality by choosing to interpret their terms in such a way so as to prevent conflicts with this nation's bedrock principles. ${ }^{217}$ A court need not conclude that a broader reading in fact violates the Constitution before avoiding the broader interpretation; it must only find that a broader reading could possibly be unconstitutional. ${ }^{218}$ The avoidance canon is a tool to help courts decide between competing interpretations of a statutory text when both of which are fairly possible and one of which may violate the Constitution. ${ }^{219}$

In INS v. St. Cyr, the Supreme Court summarized the modern avoidance canon and when to employ it:

First, as a general matter, when a particular interpretation of a statute invokes the outer limits of Congress' power, we expect a clear indication that Congress intended that result. Second, if an otherwise acceptable construction of a statute would raise serious constitutional problems, and where an alternative interpretation of the statute is "fairly possible," we are obligated to construe the statute to avoid such problems. $^{220}$

\footnotetext{
214. See Storzer \& Picarello, supra note 15, at 981-82 (noting "the Equal Protection prohibitions against treating similarly situated parties differently").

215. Adrian Vermeule, Saving Constructions, 85 GEO. L.J. 1945, 1945 (1997) (quoting NLRB v. Jones \& Laughlin Steel Corp., 301 U.S. 1, 30 (1937)).

216. 5 U.S. (1 Cranch) 137 (1803).

217. Vermeule, supra note 215, at 1948-49.

218. Id.

219. Milavetz, Gallop \& Milavetz, P.A. v. United States, 130 S. Ct. 1324, 1333 (2010) (citing Clark v. Martinez, 543 U.S. 371, 381 (2005)).

220. 533 U.S. 289, 299-300 (2001) (citations omitted) (citing Edward J. DeBartolo Corp. v. Fla.
} 
A broad textual interpretation of the equal-terms provision reaches the outer limits of Congress's power. ${ }^{221}$ First, as shown above in Part IV.AB, a textual approach may not survive an Establishment Clause challenge. Even if it does survive, there is no doubt that it will force the Supreme Court into a difficult and relatively arbitrary line-drawing exercise over the scope of Congress's power in the nether regions between the Free Exercise and the Establishment Clauses. Second, although Cutter upheld RLUIPA's institutionalized-persons provision as within the scope of Congress's Section 5 powers, ${ }^{222}$ the equal-terms provision represents a serious intrusion into an area traditionally occupied by state government. Congressional oversight of local land-use decisions is substantially different than the exemption from federal law granted to religious organizations in Amos. ${ }^{223}$ "[L]and use was one of the last bastions of true local control and one of the primary means by which communities shape their character and serve collective needs." ${ }^{224}$ One alteration in a land-use regulation or granting of a conditional-use permit can alter the character of a neighborhood or purposes of a district. ${ }^{225}$

One needs to look no further than Bellmore, New York to see how an overly aggressive equal-terms provision could affect a neighborhood. After a church was allowed to locate in one of Bellmore's residential districts, it quickly expanded its offerings. ${ }^{226}$ The church grew from a simple church to a mini-compound, providing at times boarding services, driver's education, and a café. ${ }^{227}$ Though these are noble services that surely help the church members, they also affected the neighborhood residents or-in the parlance of the Establishment Clause-the equalterms provision's nonbeneficiaries. Property values depreciated as the church's informal twelve-car parking lot backed up to surrounding

Gulf Coast Bldg. \& Constr. Trades Council, 485 U.S. 568, 575 (1988); Ashwander v. TVA, 297 U.S. 288, 341, 345-48 (1936) (Brandeis, J., concurring); Crowell v. Benson, 285 U.S. 22, 62 (1932); United States ex rel. Att’y Gen. v. Del. \& Hudson Co., 213 U.S. 366, 408 (1909)).

221. See supra Part IV.A-B.

222. Cutter v. Wilkinson, 544 U.S. 709, 719-24 (2005).

223. See Corp. of the Presiding Bishop of the Church of Jesus Christ of Latter-Day Saints v. Amos, 483 U.S. 327, 335 (1987) (granting an exemption to churches in order to alleviate a government-created burden).

224. Hamilton, supra note 41, at 355.

225. Id.

226. Matthew Hogan, Walk in Love Church Sparks Protest, BellmorePatch (N.Y.), (Oct. 8, 2010), http://bellmore.patch.com/articles/walk-in-love-church-sparks-protest.

227. Id. 
yards. $^{228}$ Certainly, religious land uses deserve protection, which they receive from the Free Exercise Clause, the substantial-burdens provision, and a narrower, but still powerful, equal-terms provision. But it must be recognized that there are serious societal costs to granting exceptions to religious assemblies that provide numerous different services in areas where local officials already decided the use would harm the area.

After concluding that the broad interpretation reaches the limits of Congress's power because of the conflict with the Establishment Clause and the intrusion onto the functions of state governments, the second half of the avoidance test asks if another, narrower reading is fairly possible. ${ }^{229}$ Here, the interpretations by both the Third and Seventh Circuits are well-reasoned. All three circuits agree that Congress intended to codify the Free Exercise Clause into the equal-terms provision to some degree. ${ }^{230}$ The circuits also likely agree that the goal of the equal-terms provision is to guarantee equality between religious and nonreligious assemblies in land-use decisions. Two circuits apparently felt that the best way to accomplish these goals was through the similarly situated requirement. ${ }^{231}$

Lastly, although Congress intended for a broad interpretation, it did not clearly intend for the broader textual interpretation. Conversely, the narrow interpretation is not expressly against Congress's intent. In fact, adopting a similarly situated requirement and strict liability better fulfills Congress's intent. Not only does it limit local officials' discretion while increasing protection for religious land uses, it also prevents some of the bizarre occurrences that a broad, textual interpretation would lead to and renders the equal-terms provision immune from Establishment Clause challenges. For instance, under a strictly textual approach, it may be difficult to create entertainment districts lined with bars and restaurants to rejuvenate a district because a church would also have the option of

228. Id.

229. See text accompanying note 219.

230. See World Outreach Conference Ctr. v. City of Chicago, 591 F.3d 531, 534 (7th Cir. 2009) ("If we're right that section 2000cc(a)(1) of RLUIPA codifies Sherbert v. Verner, there isn't much point to a plaintiff's adding a claim under 42 U.S.C. § 1983 alleging a Sherbert-type violation of the free exercise clause ....”); Lighthouse Inst. for Evangelism, Inc. v. City of Long Branch, 510 F.3d 253, 264 (3d Cir. 2007) ("It is undisputed that, when drafting the Equal Terms provision, Congress intended to codify the existing jurisprudence interpreting the Free Exercise Clause.”); Midrash Sephardi, Inc. v. Town of Surfside, 366 F.3d 1214, 1232 (11th Cir. 2004) ("RLUIPA’s equal terms provision codifies the Smith-Lukumi line of precedent.”).

231. See supra Part III.B-C. 
locating in such a district. At last count, nineteen states bar the issuance of liquor licenses to businesses located near churches ${ }^{232}$ and fifteen states leave the option to localities to do the same. ${ }^{233}$ Unless the Eleventh Circuit takes the advice from Judge Sykes of the Seventh Circuit by modifying the strict dictionary definition of the term assembly, ${ }^{234}$ any bar with a separate room for parties or meetings would fall within the dictionary definition of assembly. As was the case with Lighthouse in the Third District, allowing a church into a new bar district would give the church significant power over the city's developmental priorities. ${ }^{235}$ Religious assemblies with moral objections to activities that typically occur in bar districts-drinking and, possibly, gambling - could thus locate in the district and thwart its development.

Another example of a bizarre result that is against the express will of Congress comes from an oft-cited example in Lighthouse: "[I]f a town allows a local, ten-member book club to meet in the senior center, it must also permit a large church with a thousand members ... to locate in the same neighborhood regardless of the impact such a religious entity might have on the envisioned character of the area."236 Because a secular assembly is located in the district, then a church must be allowed as well no matter the impact on the surrounding area. ${ }^{237}$ Because acts of Congress are presumed constitutional, one cannot conclude that this is

232. Alaska Stat. AnN. § 04.11.410 (West 2007); Cal. Bus. \& Prof. Code § 23789(a) (West 1997); GA. CODE ANN. § 3-3-21 (West 2003); IDAHO CODE ANN. § 23-1011B (West 2006); 235 ILL. Comp. StAT. ANN. 5/6-11 (West 2005 \& Supp. 2011); IND. CODE ANN. § 7.1-3-21-11 (West 2005); Mich. COMP. LAWS ANN. § 436.1503 (West 2001); Miss. CodE ANN. § 67-1-51 (West 1999 \& Supp. 2010); Mo. Rev. StAt. § 311.080 (2000 \& Supp. 2008); MonT. Code AnN. § 16-3-306 (2011); NeB. REv. STAT. § 53-177 (2009 \& Supp. 2010); N.J. STAT. ANN. § 33:1-76 (West 1994); N.M. STAT. AnN. § 60-6B-10 (West 2003); N.Y. Alco. Bev. ConT. LAW § 64 (McKinney 2000 \& Supp. 2011); OHIO Rev. Code ANN. § 4303.26 (West 2008); OKLA. STAT. ANN. tit. 37, § 518.3 (West 2009); R.I. GEN. LAWS ANN. § 3-7-19 (West 2006 \& Supp. 2011); S.C. CodE ANN. § 61-6-120 (2009); Wis. STAT. ANN. § 125.68 (West 2009 \& Supp. 2010).

233. Ala. Code § 28-3-43 (2003); Colo. Rev. Stat. Ann. § 12-47-313 (West 2010); Conn. Gen. Stat. AnN. § 30-46 (West 2009); Del. Code AnN. tit. 4, § 543(c) (West 2006); Fla. StAT. ANN. § 562.45 (West 2003); IOWA CODE ANN. § 123.49 (West 2007 \& Supp. 2011); KAN. STAT. ANN. § 41-710 (2000 \& Supp. 2009); Ky. ReV. STAT. ANN. § 243.220 (West 2006); LA. REV. STAT. ANN. § 26:281 (2011); MD. CodE ANN. art. 2B, § 9-201 (West 2010); MinN. STAT. ANN. $\S 340$ A.410 (West 2004 \& Supp. 2011); 47 PA. Cons. STAT. ANN. § 4-432 (West 1997 \& Supp. 2011); Tenn. Code AnN. § 57-5-105 (West 2002 \& Supp. 2011); UtAH Code AnN. § 32B-1-202 (West 2004 \& Supp. 2011); WASH. Rev. CoDE ANN. § 66.24 .010 (West 2001 \& Supp. 2011).

234. See supra notes $169-74$ and accompanying text.

235. Lighthouse, $510 \mathrm{~F} .3 \mathrm{~d}$ at 271.

236. Id. at 268 .

237. This statement assumes the district has enough space open for a church to locate. 
the result prayed for when Congress desired equal protection for religious and nonreligious assemblies.

Before dismissing these examples as extreme, remember that, in the vast majority of cases, the textual interpretation and the similarly situated interpretation will reach the same conclusion. Only in these fringe cases will local interests hold sway in creating livable cities.

\section{Adopting the Similarly Situated Requirement and Merging the Third and Seventh Circuits' Tests}

Each of the tests presented above has problems. The Third Circuit's regulatory-purpose test fails to fully address Congress's concerns about local officials' discretionary control over religious land uses. The Seventh Circuit's test will become hard to implement outside the very limited circumstances present in River of Life. ${ }^{238}$ The problems with the Eleventh Circuit's test are myriad and addressed above. ${ }^{239}$ Unfortunately, as Judge Cudahy warned, "the search . . . for an entirely objective test is probably in vain." 240

\section{Adopting the Similarly Situated Requirement}

This Comment's main argument in favor of incorporating the similarly situated requirement is that a textual interpretation may violate the Establishment Clause and therefore must be avoided in favor of other well-reasoned tests. This approach has the added benefit of staying away from basing the test strictly on adopting the similarly situated requirement from Equal Protection Clause jurisprudence to enforce a statute based on Free Exercise Clause principles. In addition to the entirely valid reasons outlined by the Third and Seventh Circuits and at the risk of wading into this heated debate, this Comment contends that adopting the similarly situated requirement makes sense in the context of the Free Exercise Clause because it was essentially, though not explicitly, employed in previous Free Exercise Clause cases.

238. The Seventh Circuit's test will only apply if districts are zoned exclusively for one use, which is uncommon. See River of Life Kingdom Ministries v. Vill. of Hazel Crest, 611 F.3d 367, 374 (7th Cir. 2010) (en banc) ("We are likely to have cases in the future challenging zoning ordinances that are harder to classify, as variances and special-use permits and grandfathered nonconforming uses blur the character of particular zoning districts.”).

239. See supra Part IV.A-C.

240. River of Life, 611 F.3d at 374-75 (Cudahy, J., concurring). 
In Lukumi, the city passed ordinances banning animal sacrifice when it discovered that members of the Santeria religion who practiced animal sacrifice planned to locate in the city. ${ }^{241}$ The purported purpose of the ordinances was to prohibit animal sacrifice as many in the community found it inhumane or especially cruel. ${ }^{242}$ But, the statutes were narrowly written and applied so that "few if any killings of animals [were] prohibited other than Santeria sacrifice."243 The statute did not apply to Jewish groups who practiced kosher slaughter. ${ }^{244}$ Nor did it apply to other "killings that [were] no more necessary or humane in almost all other circumstances." 245

Thus, the ordinances in Lukumi failed for two reasons pertinent to the equal-terms provision, showing why the similarly situated requirement elucidates essential Free Exercise Clause principles. ${ }^{246}$ First, after comparing how the law's purpose of forbidding religious killings affected the Santeria religion and similarly situated religious killings by those associated with Judaism, it was clear the city allowed some religious killings while it disallowed others, thereby affecting the ordinances' proffered purpose. ${ }^{247}$ Second, after comparing how the law's purpose of forbidding inhumane killings affected the types of killings by the Santeria members and other similarly situated methods of killings by others, it was clear the city allowed similar inhumane methods of killing by others that had the same effect on the ordinance's purpose. ${ }^{248}$ As the similarly situated requirement is essentially what the Supreme Court used in Lukumi, there is an argument that it does not come solely from Equal Protection Clause cases.

\footnotetext{
241. Church of the Lukumi Babalu Aye, Inc. v. City of Hialeah, 508 U.S. 520, 525-26 (1993).

242. Id. at 535 .

243. Id. at 536 .

244. Id.

245. Id.

246. The ordinances in Lukumi also failed because the officials evinced a pattern of discrimination in passing the ordinances, which showed a discriminatory intent. Id. at 545-46 ("[E]ach of Hialeah's ordinances pursues the city's governmental interests only against conduct motivated by religious belief. ... This precise evil is what the requirement of general applicability is designed to prevent.”).

247. Id. at 536 .

248. Id. at 537.
} 


\section{Merging the Third and Seventh Circuits' Tests}

After concluding that the similarly situated requirement is needed, the remainder of this Section discusses which, if any, test should be adopted. This Section argues that the Seventh Circuit's regulatorypurpose test should control when possible, but in many cases the test will be inapplicable because it is very narrow and many land-use controls are inherently legislative. In this case, the Third Circuit's test should control.

The Third and Seventh Circuits' tests will lead to the same result on the great majority of cases because a district's regulatory purpose will generally dictate its regulatory criteria. ${ }^{249}$ If the purpose is to generate taxes, then the district will have commercial regulatory criteria. When possible, the Seventh Circuit's regulatory-criteria test should control. The test limits local officials' discretion and self-serving testimony to the greatest extent possible while still narrowing the equal-terms provision's scope to prevent a collision with the Establishment Clause. Courts may employ this construction whenever a district is zoned all commercial or all residential. For instance, it could be employed in determining if Park51 should be allowed into the district in lower Manhattan. The district is a general commercial zone and allows for virtually any commercial use except adult-entertainment clubs. ${ }^{250}$ A reviewing court would not need to look any further than New York City's Commercial District Use Regulations to see that disallowing Park51 would be contrary to the district's stated regulatory criteria. ${ }^{251}$ Such a test forces officials to be honest about their zoning requirements when they design the code and encourages them to be forthright with what they will and will not allow in a district.

But many districts and many land-use devices - conditional-use permits and zoning variances come to mind-cannot avoid some level of discretionary judgment. Unless society is ready to rid itself of these helpful devices, a proper test must account for them. For instance, churches are commonly listed as conditional uses and may locate in a

249. See River of Life Kingdom Ministries v. Vill. of Hazel Crest, 611 F.3d 367, 374 (7th Cir. 2010) (en banc) (Cudahy, J., concurring) (“[T]he practical distinction between 'regulatory purpose' and 'regulatory criteria' may not be as pronounced as the majority opinion suggests.”).

250. N.Y.C., N.Y. ZONING ResOlUTION art. III, ch. 2, §32-00-01 (2011), available at http://www.nyc.gov/html/dcp/pdf/zone/art03c02.pdf.

251. Id. 
district only if certain conditions are met. ${ }^{252}$ Granting a conditional-use permit "results from a legislative determination that such use will not ordinarily be detrimental or injurious to the neighborhood within the zone.”253 Zoning boards must consider certain criteria that help them account for potential problems in deciding whether to grant the conditional-use permit and allow the use in the area. ${ }^{254}$ The criteria, though, are often vague to the point of unhelpful—some ordinances only state that the conditional use must be " "consistent with the public health, welfare, and safety'” in the district. ${ }^{255}$ If the regulatory criteria are broad, then they will not be especially helpful in eliminating discretion, and the court will have to fall back to considering the regulatory purpose.

One way to limit discretion is to closely scrutinize the zoning codes and encourage or compel officials to justify a regulation's purposes in writing. ${ }^{256}$ If the code does not provide a regulatory purpose, then the religious assembly should automatically be granted entry into the district. If the city does not provide a regulatory purpose, then it cannot show how a religious assembly would harm that district.

The regulatory-criteria test is not unreasonable. Regulatory purposes are not as easily disguised as critics contend, and decades of land-use decisions highlight proper regulatory purposes. Further, judges often pass on self-serving testimony. In analyzing the substantial-burdens provision and the Free Exercise Clause, judges must determine the validity of testimony and the likelihood that the predicted harms will result from the proposed land use. Federal judges can determine when a local regulation impermissibly targets a religious assembly or whether a city's reasoning or justification for doing so is unpersuasive, just as they do in free exercise and substantial-burdens cases.

252. Shelby D. Green, Zoning In and Out Churches: Limits on Municipal Zoning Powers by the Religious Land Use and Institutionalized Persons Act, 37 REAL EST. L.J. 163, 169 (2008) ("Many municipalities have included religious operations in the category of uses requiring special permits or special exceptions, particularly in areas zoned residential.”).

253. Cope v. Inhabitants of Brunswick, 464 A.2d 223, 226-27 (Me. 1983) (citing Cmty. Sch., Inc. v. Zoning Bd. of Appeals, 369 A.2d 1146, 1149 (Me. 1977)).

254. SPRANKLING, supra note 62 , § 37.04 .

255. Id.

256. The Third Circuit did this to a degree in Lighthouse. See supra note 136-38 and accompanying text (stating that the Lighthouse court found an equal-terms violation in part because the city did not have a regulatory purpose for the court to compare the church against to see if it would harm the district). 


\section{CONCLUSION}

The Eleventh Circuit's textual approach is not simply a codification of the Smith-Lukumi free exercise line of cases. A textual interpretation results in an accommodation greater than that required by free exercise jurisprudence because this approach does not allow a city to escape liability even if its law is neutral and generally applicable. Further, it is an impermissible accommodation because strict scrutiny is not required, which results in a textual approach that fails to account for the law's burdens on its nonbeneficiaries. Courts should avoid this improper interpretation and combine the best parts of the Third and Seventh Circuits' tests. This modified test tracks Congress's intent to limit individualized discretion and ensures equal, not preferred, treatment. 